УДК 622.271:504.062

ДОСЛІДЖЕННЯ ТЕХНОЛОГІЇ ГІРНИЧОТЕХНІЧНОЇ РЕКУЛЬТИВАЦІЇ В ПРОЦЕСІ ВІДКРИТОЇ РОЗРОБКИ ПОЛОГИХ РОДОВИЩ 'Корсунський Г.Я., ' Павличенко А.В., 'Конопльова О.О.

${ }^{1}$ Національний технічний університет «Дніпровська політехніка»

ИССЛЕДОВАНИЕ ТЕХНОЛОГИИ ГОРНОТЕХНИЧЕСКОЙ РЕКУЛЬТИВАЦИИ В ПРОЦЕССЕ ОТКРЫТОЙ РАЗРАБОТКИ ПОЛОГИХ МЕСТОРОЖДЕНИЙ

${ }^{1}$ Корсунский Г.Я., ${ }^{1}$ Павличенко А.В., ${ }^{1}$ Коноплева Е.А.

${ }^{1}$ Национальный технический университет "Днепровская политехника»

\title{
RESEARCH OF TECHNOLOGY OF MINING AND TECHNICAL RECULTIVATION IN THE PROCESS OF OPEN DEVELOPMENT OF FLAT FIELDS OF DEPOSITS ${ }^{1}$ Korsunskyi H.Ya., ${ }^{1}$ Pavlychenko A.V., ${ }^{1}$ Konopleva O.O. \\ ${ }^{1}$ National Technical University «Dnipro Polytechnic»
}

Анотація. Функціонування гірничих підприємств призводить до руйнування земної поверхні, порушення водоносних горизонтів та забруднення прилеглих територій. В гірничодобувних регіонах спостерігаються високі рівні забруднення об'єктів довкілля, що значно погіршує умови проживання населення. Саме тому виникає потреба в удосконаленні технологічних схем технічної та біологічної рекультивації земель, що порушені в результаті багаторічної розробки родовищ корисних копалин.

Запропоновано оригінальний підхід до визначення послідовності технології гірничотехнічної рекультивації земель у процесі розробки пологих родовищ (будівництво кар'єру, розробка родовища, завершення гірничих робіт). Дослідження технології рекультиваційних робіт у часі здійснюється за трьома електронними таблицями, які вперше запропоновано в цій статті. Наведено розрахункові формули для визначення площ земель, що порушуються в процесі гірничих робіт, і площі на внутрішніх відвалах, які послідовно відновлюються до стану, придатного для використання у сфері сільського господарства. Наведено приклад практичної реалізації запропонованого підходу з моделювання процесів виймання чорнозему, потенційно-родючих суглинків та їх розміщення на спланованому внутрішньому відвалі в умовах Нікопольського марганцеворудного басейну. Обґрунтовано комплекс заходів, спрямованих на відновлення порушених відкритими гірничими роботами земель та повернення їх до стану, придатного для сільськогосподарського використання.

Впровадження і застосування розроблених технологічних рішень дозволить зменшити негативний вплив гірничих робіт на навколишне середовище при розробці родовищ корисних копалин. Розроблені методики вибору технологій захисту ґрунтів при видобутку мінеральної сировини дозволяють покращити екологічний стан гірничопромислових регіонів та сприятимуть сталому функціонуванню добувної галузі України.

Ключові слова: пологі родовища корисних копалин, гірничотехнічна рекультивація земель, чорнозем, суглинки, зовнішні відвали, внутрішні відвали, етапи розробки родовища.

Вступ. В Україні для видобування корисних копалин широко застосовується відкритий спосіб розробки родовищ. Особливістю відкритих гірничих робіт $\epsilon$ необхідність тимчасового відчуження значних площ сільськогосподарських земель [1-4]. Загальна площа земель, що порушені видобуванням корисних копалин, досягає сотні тисяч гектарів [5-7].

У зв'язку з цим, для відновлення земель, порушених відкритими гірничими роботами, необхідно в процесі розробки пологих родовищ в першу чергу проводити гірничотехнічну рекультивацію площ внутрішніх породних відвалів.

Гірничотехнічна рекультивація - це перший етап комплексу робіт 3 рекультивації земель. Задача гірничотехнічної рекультивації - підготовка порушених земель до проведення заходів з подальшого відновлення родючості порушених земель. 
Для цього необхідно виконати планування площі внутрішнього відвала 3 ухилом до 2-3 для відводу атмосферних вод. Після того, як в відвальних породах відбудеться усадка порід (2-3 роки), на поверхні внутрішнього відвалу розташовують суглинки (3-4 м), які зверху покривають шаром чорнозему 0,40,5 м. Сучасна та якісна рекультивація порушених гірничими роботами земель повинна забезпечити відновлення продуктивності та родючості порушених земель, що має мінімізувати негативний вплив відкритих гірничих робіт на природне середовище. При виборі напряму рекультивації слід враховувати те, що ті землі, які підлягають рекультивації, і ті, що знаходяться поблизу, після закінчення робіт повинні представляти собою оптимально сформовану територію ландшафту [8-11].

Метою роботи є дослідження технології гірничотехнічної рекультивації в процесі відкритої розробки пологих родовищ на основі запропонованої методики, що складається 3 трьох взаємопов'язаних електронних таблиць. У першу таблицю вносяться вихідні дані, які стосуються гірничо-геологічних умов залягання родовища корисних копалин; в другій таблиці по заданих формулах виконується гірничо-геометричний аналіз родовища; а в третій таблиці виконуються розрахунки щодо приведеної дослідженої технології гірничотехнічної рекультивації в процесі відкритої розробки пологого родовища.

Основна частина. Гірничотехнічна рекультивація здійснюється у процесі розробки родовища. Виїмка чорнозему вже здійснюється на етапі будівництва кар'єру при проведені капітальної і розрізної траншей. Крім виїмки чорнозему рекомендується виймати також суглинки. Чорнозем і суглинки в подальшому використовуються для покриву внутрішнього відвалу.

Після будівництва кар'єру в процесі розробки пологого родовища продовжується виймання чорнозему і суглинків перед фронтом робіт, які в подальшому також розміщуються на спланованому внутрішньому відвалі, після необхідної усадки відвальних порід.

Після завершення розробки родовища на поверхні землі залишаються капітальна, виїзна й остаточна траншеї. 3 економічної точки зору ці траншеї не засипають породою, а заповнюють водою 3 метою подальшого використання для рекреації місцевими мешканцями.

Основними технологічними процесами при гірничотехнічній рекультивації земель, порушених гірничими роботами, є: підготовка площі гірничого відводу кар'єру до знімання чорнозему; виймання та завантаження шару чорнозему; транспортування чорнозему до тимчасових складів або безпосередньо на рекультивовану поверхню відвалу; виймання та завантаження потенційнородючих порід (суглинків) та транспортування їх на поверхню внутрішнього відвалу.

Технологія робіт при гірничотехнічній рекультивації визначається прийнятою системою розробки родовищ. Розглянемо процес гірничотехнічної рекультивації порушених земель при безтранспортній системі розробки. Особливістю цієї системи є те, що розробка родовища здійснюється одним уступом висотою до 25 м в залежності від типу крокуючого екскаватору драглайну (без використання автомобільного транспорту). 
Розглянемо динаміку гірничотехнічної рекультивації в три етапи при розробці пологих родовищ одним уступом за безтранспортною системою.

Eman 1 - проведення капітальної та розрізної траншей (рис. 1).

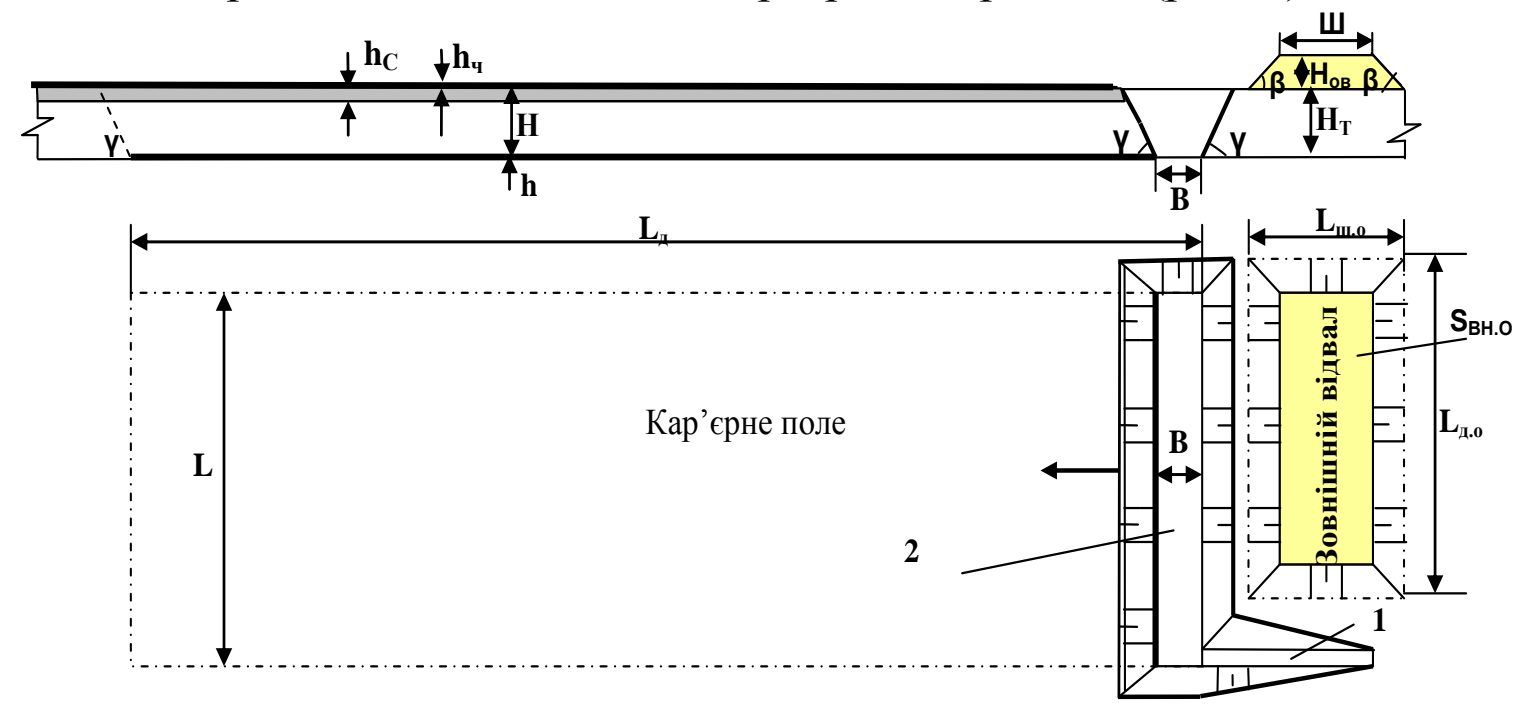

Рисунок 1 - Будівництво кар'єру: 1 - капітальна траншея; 2 - розрізна траншея; - напрямок переміщення фронту робіт

Ширину зовнішнього відвалу визначаємо за формулою:

$$
L_{\text {Ш.O }}=\frac{V_{K}+V_{P}-H_{O . B}^{2} \operatorname{ctg} \beta L_{\text {д.O }}+0,5 H_{O . B}^{3} \operatorname{ctg}^{2} \beta}{H_{O . B} L_{\text {д.O }}+H_{O . B}^{2} \operatorname{ctg} \beta}, \mathrm{M}
$$

де $V_{K}$ - об'єм капітальної траншеї, м³ $V_{P}$ - об’єм розрізної траншеї, м³ $H_{O . B}-$

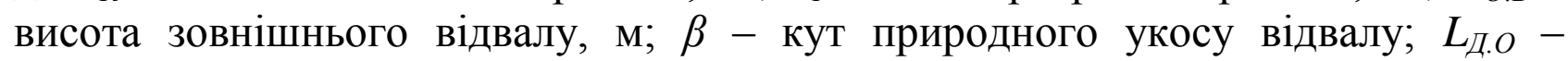
довжина зовнішнього відвалу, м.

Об’єм чорнозему під зовнішній відвал визначаємо за формулою:

$$
V_{\text {Ч.BH.O }}=L_{\text {Ш.O. }} L_{\text {Д.O. }} h_{\Psi}, \mathrm{M}^{3}
$$

де $h_{\Psi}-$ потужність чорнозему, м.

Площа земель під розрізну траншею:

$$
S_{P . T .}=\left(L+2 H_{T} \operatorname{ctg} \gamma\right)\left(B+H_{T} \operatorname{ctg} \gamma+H_{T} \operatorname{ctg} \beta\right), \mathrm{M}^{2}
$$

де $L$ - ширина кар'єрного поля по корисній копалині, м; $\gamma$ - кут укосу розкривного уступу, град.

Об’єм чорнозему, знятого з верхньої площі розрізної траншеї:

$$
V_{Y . P, T}=S_{P . T .} h_{\Psi}, \mathrm{M}^{3}
$$

Площу земель під капітальну траншею визначаємо за формулою:

$$
S_{K . T}=\frac{\left(b+H_{T} \operatorname{ctg} \gamma\right) H_{T}}{i}, \mathrm{M}^{2}
$$


де $\gamma$ - кут укосу розкривного уступу; $b$ - ширина капітальної траншеї по низу, м; $i$ - нахил капітальної траншеї, тис. \%о; $H_{T}$ - глибина кар'єру, м.

Об’єм чорнозему, знятого з верхньої площі капітальної траншеї:

$$
V_{Y . K . T}=S_{K . T} h_{\Psi}, \mathrm{M}^{3}
$$

Eman 2 - розробка родовища корисної копалини (рис. 2).

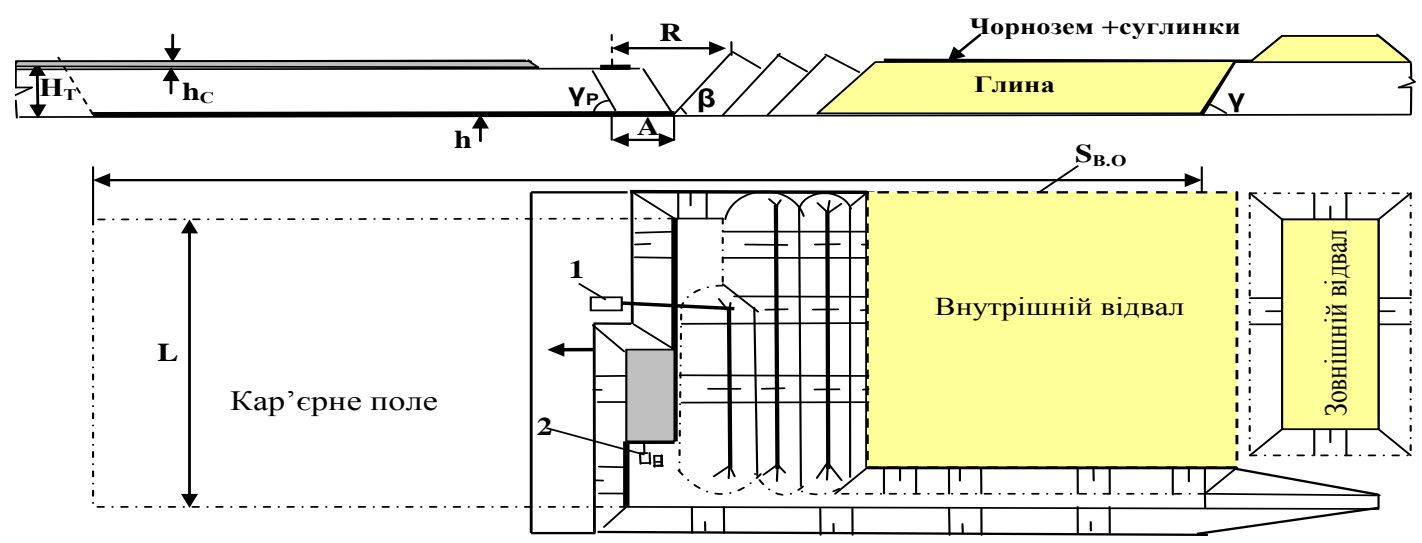

1 - крокуючий екскаватор (драглайн); 2 - видобувний екскаватор

Рисунок 2 - Розробка родовища корисних копалин

Площа земель під внутрішній відвал:

$$
S_{B H . O}=\left(L+H_{T} \operatorname{ctg} \gamma-b_{B}-H_{0} \operatorname{ctg} \beta\right)\left(L_{\text {д }}+H_{T} \operatorname{ctg} \gamma-B-H_{0} \operatorname{ctg} \beta\right), \mathrm{M}^{2}
$$

де $H_{T}$ - глибина кар'єру, м; $\gamma$ - кут укосу розкривного уступу; $b_{B}$ - ширина виїзної траншеї по низу, м; $\beta$ - кут укосу уступу відвалу, град; $B$ - ширина по низу залишкової траншеї, м; $L_{д}-$ довжина кар'єрного поля, м; $H_{O}-$ висота внутрішнього відвалу, м.

Об’єм чорнозему, знятого з площі кар'єрного поля:

$$
V_{Y . B H . O}=S_{B . O} h_{\Psi}, \mathrm{M}^{3}
$$

Річне посування фронту робіт:

$$
\Pi_{\Gamma}=\frac{Q_{K}}{L h \rho}, \text { м/год. }
$$

де $Q_{\kappa}-$ продуктивність кар’єру по корисній копалині, т/год; $h_{Y}-$ потужність чорнозему, м; $\rho$ - щільність корисної копалини, т/ $\mathrm{M}^{3} ; S_{B . O}-$ площа внутрішнього відвалу, м².

Щорічний об’єм чорнозему, що виймається в процесі розробки родовища:

$$
V_{\Gamma . Y}=\left(L+2 H_{T} \operatorname{ctg} \gamma\right) h \Pi_{\Gamma}, \mathrm{M}^{3}
$$

Тривалість розробки родовища: 


$$
T_{\Pi}=\frac{L_{д} L h \rho}{Q_{K}}, \text { років }
$$

Річна площа внутрішнього відвалу, що рекультивується:

$$
S_{P . B H . O}=\Pi_{\Gamma}\left(L+H_{T} \operatorname{ctg} \gamma-b_{B}-H K_{P} \operatorname{ctg} \beta\right), \mathrm{M}^{2}
$$

де $K_{P}$ - коефіцієнт розпушення розкривних порід.

Eman 3 - завершення розробки родовища корисних копалин (рис. 3).

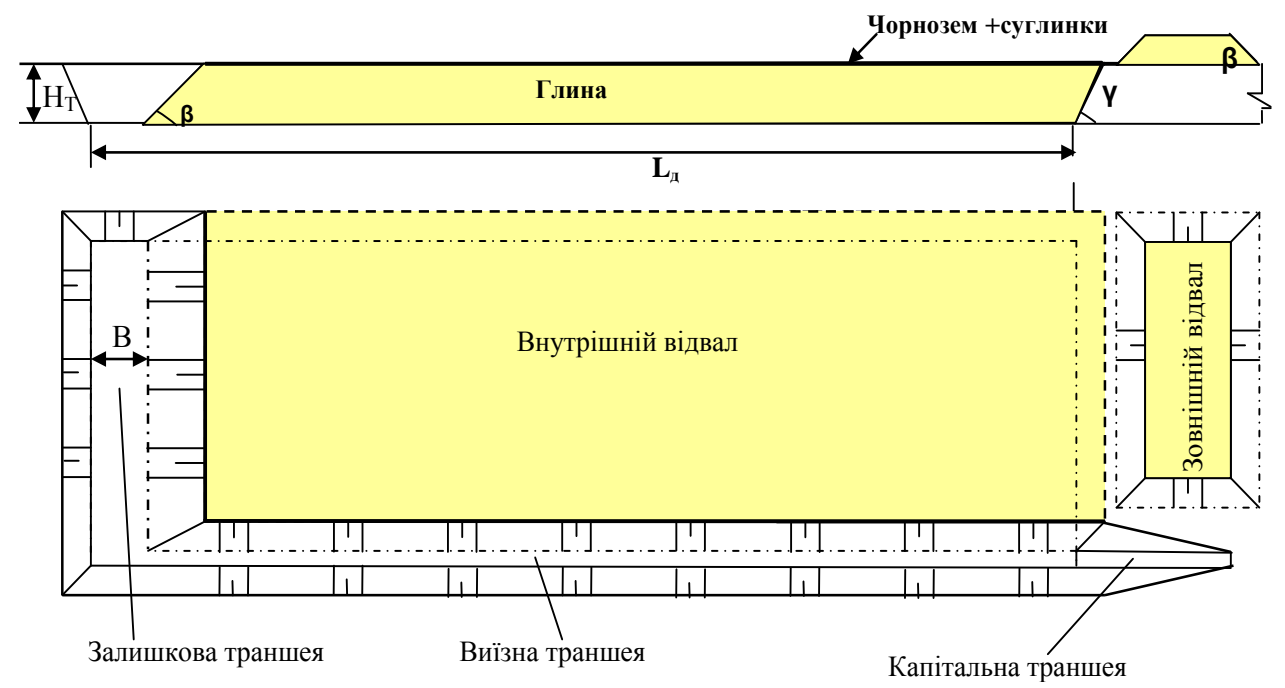

Рисунок 3 - Завершення розробки родовища

Площа землі під виїзну траншею визначається за формулою:

$$
S_{B T}=\left(L_{\text {д }}-B-H K_{P} \operatorname{ctg} \beta\right)\left(H_{T} \operatorname{ctg} \gamma+b_{B}+H K_{P} \operatorname{ctg} \beta\right), \mathrm{M}^{2}
$$

Площа під залишкову траншею визначається за формулою:

$$
S_{O . T}=\left(L+2 H_{T} \operatorname{ctg} \gamma\right)\left(H_{T} \operatorname{ctg} \gamma+B+H K_{P} \operatorname{ctg} \beta\right), \mathrm{M}^{2}
$$

Апробуємо приведену методику для дослідження технології гірничотехнічної рекультивації в процесі відкритої розробки родовища в гірничотехнічних умовах Нікопольського марганцеворудного басейну.

Вихідні дані: нахил капітальної траншеї, тис. \%о $(i=0,06)$; ширина капітальної траншеї по низу, м $(b=30)$; ширина розрізної траншеї по низу, м $(B=40)$; кут укосу відвальних порід, град $(\beta=30)$; кут укосу розкривних порід, град $(\gamma=45)$; висота зовнішнього відвалу, м $($ Но.в $=25)$; коефіцієнт розпушення розкривних порід $(K p=1,2)$; відставання рекультиваційних робіт від початку розробки родовища, років $(t=2)$; щільність корисної копалини, т/м ${ }^{3}(p=2)$; виробнича потужність кар'єру по корисній копалині, т/рік $(Q=1000000)$; довжина кар'єрного поля, м (1000).

На підставі вихідних даних (табл. 1) згідно розробленої методики виконуємо в режимі Excel гірничо-геометричний аналіз родовища. Результати розрахунку наведені в електронній таблиці (табл. 2). 
Таблиця 1 - Вихідні дані по свердловинах для дослідження технологій рекультиваційних робіт в заданому кар'єрному полі

\begin{tabular}{|c|c|c|c|c|c|c|c|c|c|c|c|c|c|c|c|c|}
\hline \multirow{2}{*}{$\begin{array}{c}\text { № } \\
\text { блока }\end{array}$} & \multicolumn{4}{|c|}{ Св. №1 } & \multicolumn{4}{|c|}{ Св. №2 } & \multicolumn{4}{|c|}{ Св.№3 } & \multicolumn{4}{|c|}{ Св. №4 } \\
\hline & \multirow{2}{*}{\begin{tabular}{|c|}
$H, \mathrm{M}$ \\
50
\end{tabular}} & \multirow{2}{*}{$\frac{h, \mathrm{M}}{1,5}$} & \multirow{2}{*}{$\frac{h_{c}, \mathrm{M}}{3}$} & \multirow{2}{*}{$\begin{array}{c}h_{u}, \mathrm{M} \\
0,2\end{array}$} & \multirow{2}{*}{$\frac{H, \mathrm{M}}{57}$} & \multirow{2}{*}{$\frac{h, \mathrm{M}}{2,4}$} & \multicolumn{2}{|c|}{$h_{c}, \mathrm{M} h_{\psi}, \mathrm{M}$} & \multirow{2}{*}{$\begin{array}{c}H, \mathrm{M} \\
59\end{array}$} & \multirow{2}{*}{$\begin{array}{l}h, \mathrm{M} \\
2,9\end{array}$} & \multicolumn{2}{|c|}{$h_{c}, \mathrm{M} h_{\psi}, \mathrm{M}$} & \multirow{2}{*}{$\begin{array}{c}H, \mathrm{M} \\
62\end{array}$} & \multirow{2}{*}{$\begin{array}{c}h, \mathrm{M} \\
1,9\end{array}$} & \multicolumn{2}{|c|}{$h_{c}, \mathrm{M} h_{\psi}, \mathrm{M}$} \\
\hline 1 & & & & & & & 3 & 0,6 & & & 5 & 0,4 & & & 3 & 0,4 \\
\hline 2 & 52 & 2 & 4 & 0,3 & 60 & 2,5 & 2 & $J$ & 60 & 2,3 & 4 & 5 & 59 & 1,8 & 2 & J, \\
\hline 3 & 5 & 9 & 5 & 0 & 58 & 2,7 & 2 & 4 & 57 & 2,4 & 3 & 6 & 57 & 2,1 & 2 &, 4 \\
\hline 4 & 53 & 1,8 & 4 & 0 & 59 & 2,9 & 3 & 3 & 57 & 2,5 & 5 & 5 & 54 & 2,3 & 3 & 0,5 \\
\hline 5 & 54 &, 1 & 3 & 0 & 60 & 2,3 & 4 & 0,4 & 58 & 3 & 2 & 0,4 & 57 & 2,6 & 4 & 0,2 \\
\hline 6 & 8 & 3 & 2 & & 57 & 2,4 & $J$ & & 59 & 2,1 & 3 & 3 & 60 & 8 & 5 & 3 \\
\hline 7 & & 2,4 & 2 & & 57 & 2,5 & 3 & & 0 & 2,3 & 3 & & 58 & 2,7 & 3 & 0,4 \\
\hline \multirow{2}{*}{$\begin{array}{c}\text { № } \\
\text { блоку } \\
\end{array}$} & \multicolumn{4}{|c|}{ Св. №5 } & \multicolumn{4}{|c|}{ Св. №6 } & \multicolumn{4}{|c|}{ Св. №7 } & \multicolumn{4}{|c|}{ Св. №8 } \\
\hline & $H, \mathrm{м}$ & $h, \mathrm{M}$ & $h_{c}, \mathrm{M}$ & $h_{u}, \mathrm{M}$ & $H, \mathrm{~m}$ & $h, \mathrm{M}$ & $h_{c}, \mathrm{~N}$ & $h_{u}, \mathrm{M}$ & $H, \mathrm{M}$ & $h, \mathrm{M}$ & $h_{c}, \mathrm{I}$ & $n_{4}, \mathrm{M}$ &, $\mathrm{M}$ & $h, \mathrm{M}$ & $h_{c}, \mathrm{M}$ & $n_{n_{i}, \mathrm{M}}$ \\
\hline 1 & 50 & 2,2 & 5 & 0,4 & 54 & 2,9 & 5 & 0,3 & 59 & 2,4 & 5 & 0,4 & 57 & 1,9 & 2,5 & 0,4 \\
\hline 2 & 5 & 2,1 & 4 & 0,5 & 57 & 2. & 3 & 04 & 57 & 1,5 & 4 & 0,5 & 54 & o & 2,3 & 0,5 \\
\hline 3 & 55 & 2,3 & 3 & 0 & 60 & 2,4 & 4 & 5 & 58 & 2 & 3 & 0,5 & 57 & 2,1 & 2,6 & 0,2 \\
\hline 4 & 53 & 2,6 & 2 & 0,5 & 58 & 2,5 & 5 & 0,2 & 59 & 9 & 3 & 0,4 & 60 & 3 & 2,7 & 0,3 \\
\hline 5 & 54 & 2,8 & 2 & 0 & 59 & 3 & 4 & 0,3 & 54 & 1,8 & 2 & 0,3 & 58 & 2,6 & 2,4 & 0,4 \\
\hline 6 & 57 & 1 & 3 & 0, & 60 & 2,4 & 3 & 0 & 57 & 2,1 & 2 & 0,4 & $y$ & 8 & 2,5 & 0,5 \\
\hline 7 & 57 & 2,7 & 4 & 0,4 & 58 & 2,5 & 2 & 0,6 & 60 & 2,3 & 3 & 0,5 & 60 & 2,7 & 2,8 & 0,6 \\
\hline
\end{tabular}

Таблиця 2 - Гірничо-геометричний аналіз пологого родовища (початок розробки родовища 2018 р., ширина блоку $L u=100$ м, довжина блоку $L \partial=1300$ м)

\begin{tabular}{|c|c|c|c|c|c|c|c|c|c|c|c|c|c|}
\hline \multirow[t]{2}{*}{ 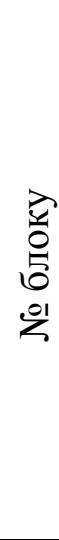 } & 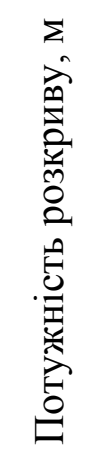 & 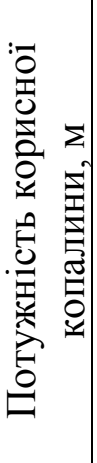 & 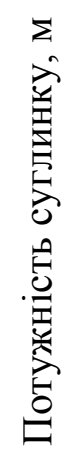 & 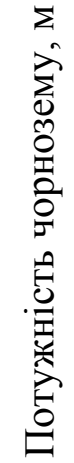 & 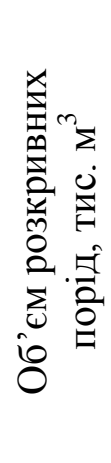 & 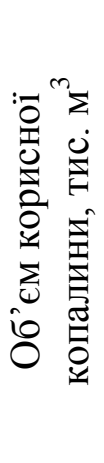 & 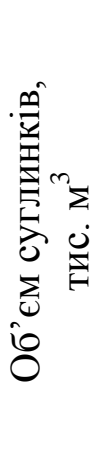 & 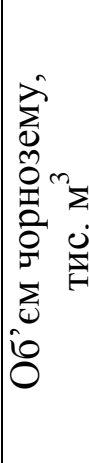 & 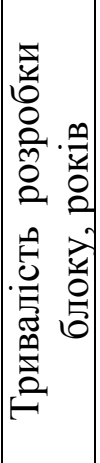 & & 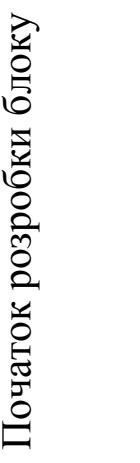 & \multicolumn{2}{|c|}{ 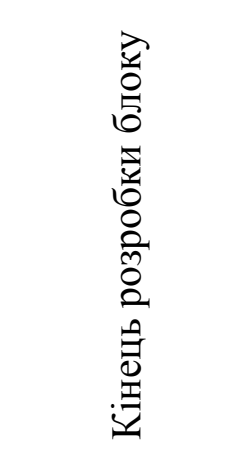 } \\
\hline & $H$ & $h$ & $h c$ & $h M$ & $V_{B}$ & Vnu & $V_{c}$ & $V u$ & $t \sigma$ & рік & місяць & рік & місяць \\
\hline 1 & 56,0 & 2,3 & 3,9 & 0,4 & 5600 & 226 & 394 & 39 & 0,5 & 2018 & 1 & 2018 & 6 \\
\hline 2 & 56,4 & 2,0 & 3,2 & 0,4 & 6765 & 244 & 379 & 52 & 0,5 & 2018 & 7 & 2018 & 12 \\
\hline 3 & 57,1 & 2,2 & 3,1 & 0,5 & 7426 & 291 & 400 & 58 & 0,6 & 2019 & 1 & 2019 & 7 \\
\hline 4 & 56,6 & 2,4 & 3,1 & 0,4 & 7927 & 329 & 432 & 56 & 0,7 & 2019 & 8 & 2020 & 3 \\
\hline 5 & 56,8 & 2,5 & 2,9 & 0,4 & 7945 & 353 & 409 & 52 & 0,7 & 2020 & 4 & 2020 & 12 \\
\hline 6 & 58,3 & 2,5 & 3,2 & 0,4 & 8737 & 367 & 478 & 60 & 0,7 & 2021 & 1 & 2021 & 9 \\
\hline 7 & 58,8 & 2,5 & 2,9 & 0,4 & 9400 & 402 & 456 & 70 & 0,8 & 2021 & 10 & 2022 & 7 \\
\hline
\end{tabular}

В електронній табл. 3, яка пов'язана з табл. 2, виконані в Excel розрахунки показників гірничотехнічної рекультивації в процесі розробки родовища. 
Таблиця 3 - Розрахунки показників гірничотехнічної рекультивації в процесі розробки родовища

\begin{tabular}{|c|c|c|c|c|c|c|c|c|c|c|c|c|c|c|c|}
\hline 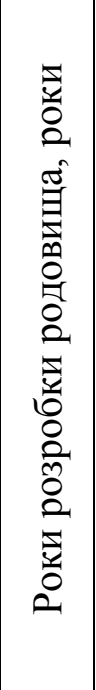 & 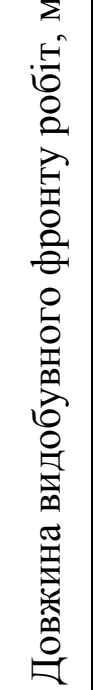 & 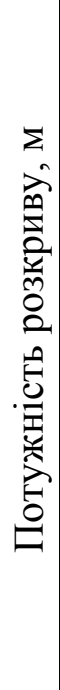 & 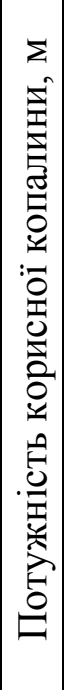 & 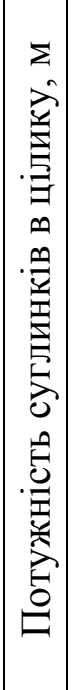 & 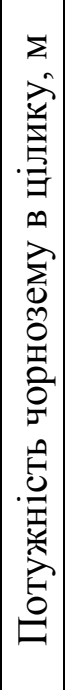 & 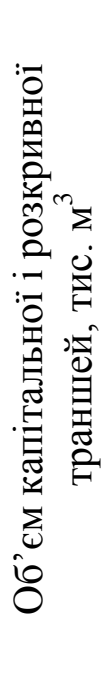 & 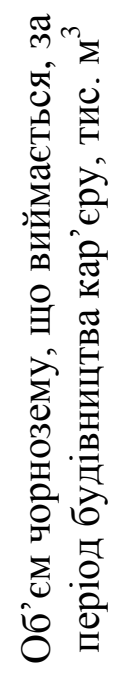 & 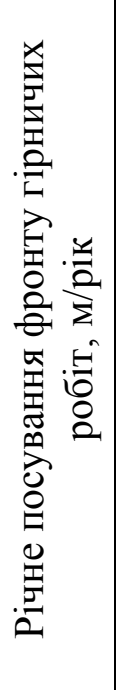 & 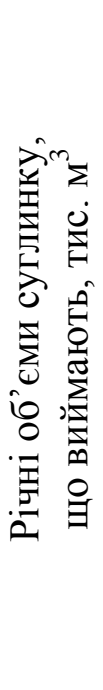 & 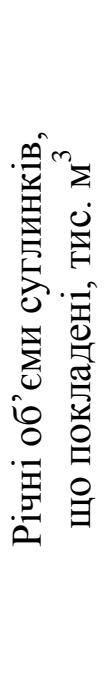 & 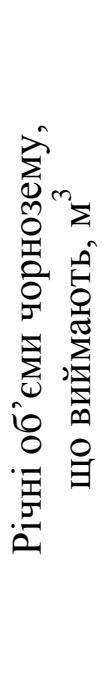 & 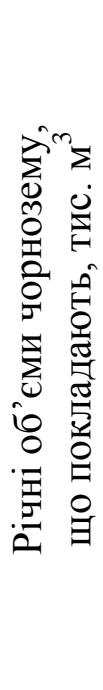 & 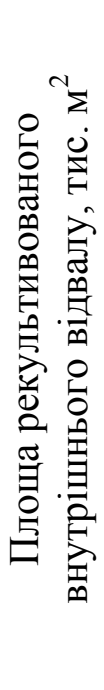 & 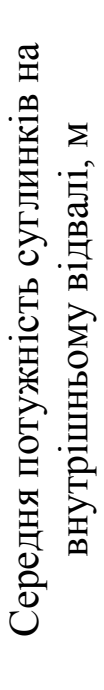 & 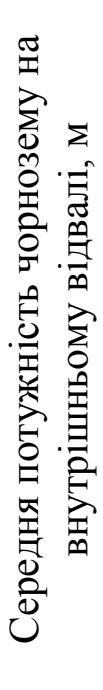 \\
\hline$T$ & $L \partial$ & $H$ & $h$ & $h c$ & $h u$ & $V m p$ & $V u$ & $\Pi_{\Gamma}$ & $V c$ & $V c$ & $V u$ & $V u$ & S6H & $h c$ & hy \\
\hline 2018 & 1300 & 56 & 2,1 & 3,5 & 0,4 & \multirow{5}{*}{2059} & \multirow{5}{*}{109,0} & 200 & 781 & 0 & 90 & 0 & 0 & 0,0 & 0,00 \\
\hline 2019 & 1300 & 57 & 2,2 & 3,1 & 0,4 & & & 162 & 671 & 0 & 93 & 0 & 0 & 0,0 & 0,00 \\
\hline 2020 & 1300 & 56 & 2,4 & 2,9 & 0,3 & & & 137 & 570 & 685 & 73 & 127 & 151 & 4,5 & 0,84 \\
\hline 2021 & 1300 & 58 & 2,4 & 3,1 & 0,4 & & & 130 & 615 & 738 & 81 & 13 & 139 & 5,3 & 0,94 \\
\hline 2022 & 1300 & 58 & 2,6 & 3,1 & 0,4 & & & 120 & 580 & 696 & 79 & 106 & 113 & 6,2 & 0,94 \\
\hline
\end{tabular}

Для наочності змінення основних показників гірничотехнічної рекультивації в часі 32018 по 2022 рр. на рис. 5 приведено графіки об’ємів виймання чорнозему та суглинків.

\section{Висновок.}

Запропоновано нову методику дослідження технології гірничотехнічної рекультивації в процесі відкритої розробки пологих родовищ, яка складається 3 трьох взаємопов'язаних електронних таблиць. В першу таблицю вносяться вихідні дані родовища корисних копалин по свердловинах, в другій електронній таблиці виконується гірничо-геометричний аналіз родовища, а в третій таблиці здійснюється дослідження технології гірничотехнічної рекультивації в процесі відкритої розробки пологого родовища.

Апробацію приведеної методики проведено для гірничо-геологічних умов Нікопольського марганцеворудного басейну. Показники технології гірничотехнічної рекультивації щодо площ і об’ємів чорнозему і суглинків, що змінюються у часі в процесі розробки родовища, приведені в відповідну таблицю. Це дає можливість планувати та виконувати гірничі роботи 3 гірничотехнічної рекультивації в процесі розробки родовищ (від будівництва кар'єру до завершення гірничих робіт). 
a)

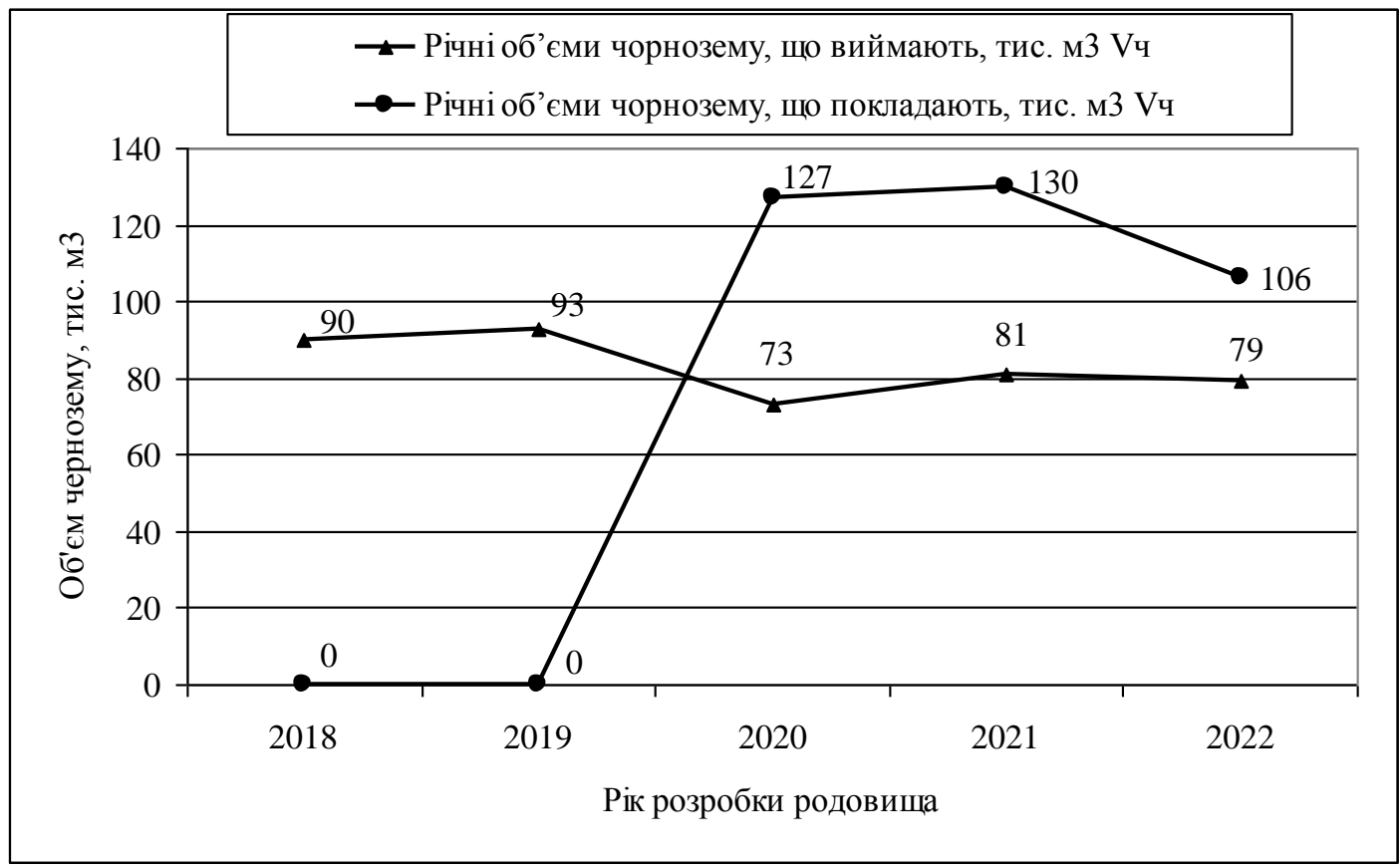

б)

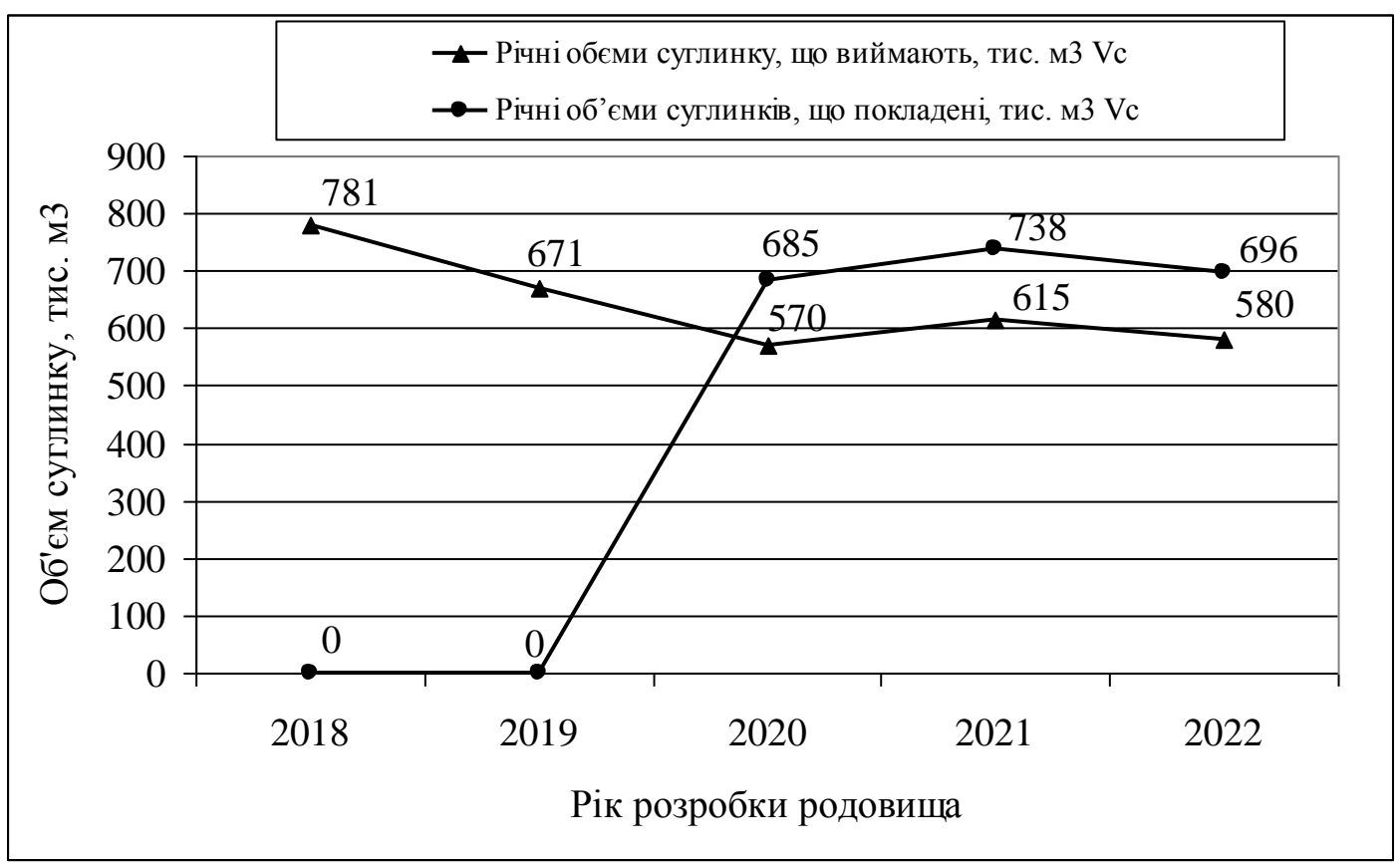

a - об’єми виймання чорнозему: б - об’єми виймання суглинків

Рисунок 5 - Графіки змінення основних показників гірничотехнічної рекультивації в часі 3 2018 по 2022 pp.

\section{СПИСОК ЛІТЕРАТУРИ}

1. Sobko, B., Drebenstedt, C. and Lozhnikov, O. Selection of environmentally safe open-pit technology for mining waterbearing deposits / Mining of Mineral Deposits. 2017, 70-75.

2. Gumenik, I., Lozhnikov, A. \& Maevskiy, A. Methodological principles of negative opencast mining influence increasing due to steady development. Geomechanical Processes during Underground Mining: School of Underground Mining. 2012, 45-49. http://dx.doi.org/10.1201/b13157-9

3. Chetverik, M., Babiy, E., \& Bubnova, E. The main technical solutions in rational excavation of minerals in open-pit mining. Annual Scientific-Technical Collection - Mining of Mineral Deposits, 2013, 173-176. https://doi.org/10.1201/b16354-31

4. Симоненко В., Гриценко Л., Черняєв А. Організація робіт з відпрацювання нерудних родовищ крутими виймальними шарами / Розробка родовищ: Зб. наук. пр. 2016. 10(4). 68-73. doi: https://doi.org/10.15407/mining10.04.068 
5. Berry P., Pistocchi A. A Multicriterial Geographical Approach for the Environmental Impact Assessment of Open-Pit Quarries I International Journal of Surface Mining, Reclamation and Environment. 2003. Vol. 17(4). P. 213-226. doi: https://doi.org/10.1076/ijsm.17.4.213.17476

6. Drebenstedt C., Ritter R., Suprun V., Agafonov Y. Cyclical-and-Continuous Method and in-Pit Crushing Operation Experience in the World / Gornyi Zhurnal. 2015. 11, 81-87. doi: https://doi.org/10.17580/gzh.2015.11.17

7. Simonenko V., Pavlychenko, A., Cherniaiev, O. Assessment of the ecological efficiency of the open development of nonmetallic deposits of useful minerals / Technology audit and production reserves. 2018, 5(3), 21-27.

8. Симоненко В.І., Павличенко, А. В., Черняєв О. В., Гриценко Л. С.Технологічні аспекти екологозберігаючої доробки нерудних кар'єрів при їх ліквідації та консервації / Вісник національного університету водного господарства та природокористування. 2016. 2, 148-158.

9. Mormul, T.M., \& Terekhov Ye.V. Environmental and economic estimation of technological solutions in terms of land resource conservation in the process of open-cast mining. Naukovyi Visnyk Natsionalnoho Hirnychoho Universytetu, 2017, 3, $122-128$.

10. Zadorozhnaya, G.A., Andrusevych, K.V., \& Zhukov, O.V. Soil heterogeneity after recultivation: ecological aspect. Folia Oecologica, 2018, 45: 46-52. doi: 10.2478/foecol-2018-0005

11. Prokopenko V.I., Litvinov Yu.l. Environmental orientable imperative of developing the technology and excavation of horizontal fields / Naukovyy visnyk Natsionalnoho Hirnychoho Universytetu. 2017. 2, 51-57.

\section{REFERENCES}

1. Sobko, B., Drebenstedt, C. and Lozhnikov, O. (2017). "Selection of environmentally safe open-pit technology for mining water-bearing deposits", Mining of Mineral Deposits, pp. 70-75.

2. Gumenik, I., Lozhnikov, A. \& Maevskiy, A. (2012) "Methodological principles of negative opencast mining influence increasing due to steady development", Geomechanical Processes during Underground Mining: School of Underground Mining, pp. 45-49. http://dx.doi.org/10.1201/b13157-9

3. Chetverik, M., Babiy, E., \& Bubnova, E. (2013). "The main technical solutions in rational excavation of minerals in open-pit mining", Mining of Mineral Deposits, pp. 173-176. https://doi.org/10.1201/b16354-31

4. Symonenko, V. Cherniaiev, O., \& Hrytsenko, L. (2016), "Organization of non-metallic deposits development by steep excavation layers". Mining of Mineral Deposits, 10(4), 68-73. doi: https://doi.org/10.15407/mining10.04.068

5. Berry, P., \& Pistocchi, A. (2003), "A Multicriterial Geographical Approach for the Environmental Impact Assessment of Open-Pit Quarries", International Journal of Surface Mining, Reclamation and Environment, vol. 17(4), pp. 213-226. doi: https://doi.org/10.1076/ijsm.17.4.213.17476

6. Drebenstedt, C., Ritter, R., Suprun, V., \& Agafonov, Y. (2015), "Cyclical-and-Continuous Method and in-Pit Crushing Operation Experience in the World" Gornyi Zhurnal, vol. 11, pp. 81-87. doi: https://doi.org/10.17580/gzh.2015.11.17

7. Simonenko, V., Pavlychenko, A., Cherniaiev, O. (2018), "Assessment of the ecological efficiency of the open development of non-metallic deposits of useful minerals", Technology audit and production reserves, vol. 5(3), pp. 21-27.

8. Symonenko, V. I., Pavlychenko, A. V., Cherniaiev O. V. and Hrytsenko L. S. (2016), "Technological aspects of ecological finalization of nonmetallic career during their liquidation and conservation", Bulletin of National University of Water Management and Nature Resources Use, no. 2, pp. 148-158.

9. Mormul, T.M., \& Terekhov Ye.V. (2017), "Environmental and economic estimation of technological solutions in terms of land resource conservation in the process of open-cast mining", Naukovyi Visnyk Natsionalnoho Hirnychoho Universytetu, vol. 3, pp. 122128.

10. Zadorozhnaya, G.A., Andrusevych, K.V., \& Zhukov, O.V. (2018), "Soil heterogeneity after recultivation: ecological aspect", Folia Oecologica, no. 45, pp. 46-52. doi: 10.2478/foecol-2018-0005

11. Prokopenko, V. I., \& Litvinov, Yu. I. (2017), "Environmental orientable imperative of developing the technology and excavation of horizontal fields", Naukovyy visnyk Natsionalnoho Hirnychoho Universytetu, vol. 2, pp. 51-57.

\section{Об авторах}

Корсунський Георгій Якович, кандидат технічних наук, доцент, професор кафедри відкритих гірничих робіт, Національний технічний університет «Дніпровська політехніка» (НТУ «ДП»), Дніпро, Україна, korsunskyi.h.ya@nmu.one

Павличенко Артем Володимирович, доктор технічних наук, професор, завідувач кафедри екології та технологій захисту навколишнього середовища, Національний технічний університет «Дніпровська політехніка» (НТУ «ДП»), Дніпро, Україна, pavlychenkoa@nmu.org.ua

Конопльова Олена Олександрівна, асистент кафедри екології та технологій захисту навколишнього середовища, Національний технічний університет «Дніпровська політехніка» (НТУ «ДП»), Дніпро, Україна, konoplova.o.o@nmu.one

\section{About the authors}

Korsunskyi Heorgiy Yakovych, Ph.D., Associate Professor, Professor of Department of Surface Mining, National Technical University "Dnipro Polytechnic" (NTU "DP"), Dnipro, Ukraine, korsunskyi.h.ya@nmu.one

Pavlychenko Artem Volodymyrovych, Doctor of Technical Science, Professor, Head of the Department of Ecology and Technologies of Environmental Protection, National Technical University "Dnipro Polytechnic" (NTU "DP"), Dnipro, Ukraine, pavlychenkoa@nmu.org.ua.

Konopleva Olena Oleksandrivna, assistant lecturer of the Head of the Department of Ecology and Technologies of Environmental Protection, National Technical University "Dnipro Polytechnic" (NTU "DP"), Dnipro, Ukraine, konoplova.o.o@nmu.one 
Аннотация. Функционирование горных предприятий приводит к разрушению земной поверхности, нарушению водоносных горизонтов и загрязнению прилегающих территорий. В горнодобывающих регионах наблюдаются высокие уровни загрязнения объектов окружающей среды, что значительно ухудшает условия проживания населения. Именно поэтому возникает потребность в усовершенствовании технологических схем технической и биологической рекультивации земель, нарушенных в результате многолетней разработки месторождений полезных ископаемых.

Предложен оригинальный подход к определению последовательности технологии горнотехнической рекультивации земель в процессе разработки пологих месторождений (строительство карьера, разработка месторождения, завершения горных работ). Исследование технологии рекультивационных работ во времени осуществляется по трем электронным таблицам, которые впервые предложены в этой статье. Приведены расчетные формулы для определения площадей земель, которые нарушаются в процессе горных работ, и площади на внутренних отвалах, которые последовательно восстанавливаются до состояния, пригодного для использования в сфере сельского хозяйства. Приведен пример практической реализации предложенного подхода для моделирования процессов выемки чернозема, потенциально-плодородных суглинков и их размещение на спланированном внутреннем отвале в условиях Никопольского марганцеворудного бассейна. Обоснован комплекс мероприятий, направленных на восстановление нарушенных открытыми горными работами земель и возвращение их в состояние, пригодное для сельскохозяйственного использования.

Внедрение и применение разработанных технологических решений позволит снизить негативное влияние горных работ на окружающую среду при разработке месторождений полезных ископаемых. Разработанные методики выбора технологий защиты почв при добыче минерального сырья позволяют улучшить экологическое состояние горнопромышленных регионов и будут способствовать устойчивому фуннкционированию добывающей отрасли Украины.

Ключевые слова: пологие месторождения полезных ископаемых, горнотехническая рекультивация земель, чернозем, суглинки, внешние отвалы, внутренние отвалы, этапы разработки месторождения.

Annotation. The operation of mining enterprises leads to the disturbance of the land surface, the violation of aquifers and adjacent areas contamination. In mining regions there are high levels of environmental objects pollution, which significantly impairs on population life conditions. That is why there is a need to improve the technological schemes of land technical and biological reclamation that has been affected by the long-term mining of mineral deposits.

An original approach is proposed to determine the sequence of mining technology land reclamation technology in the process of horizontal deposits development (pit building, mining deposit and before pit closure). Research of the reclamation works technology in time is carried out according to the three schemes that were first proposed in this article. The calculated formulas for determining the areas of land that are violated by mining operations and the area in the internal dumps that are consistently restored to a condition suitable for agriculture using are given. An example of the proposed approach practical realization to modelling the processes of extraction of chernozem, potentially fertile loamy loams and their placement on internal dump according to conditions of the Nikopol manganese-ore basin is given. The measures complex aimed at the restoration of land disturbed by surface mining and their return to a suitable condition for agriculture sector is substantiated.

Implementation and application of the developed technological solutions will reduce the negative impact of mining on the environment at the mineral deposits development. The developed methods of choosing technologies for protecting ground water during mining minerals can improve the ecological condition of mining regions and contribute to the sustainable functioning of the mining industry in Ukraine.

Key words: mineral deposits, mining land reclamation, chernozem, loam, external dumps, internal dumps, stages of deposit development.

Стаття надійшла до редакції 28.04. 2018.

Рекомендовано до друку д-ром техн. наук Четвериком М.C. 